ARTUR FILIPIAK

Uniwersytet im. Adama Mickiewicza w Poznaniu

Wydział Teologiczny

Zakład Katechetyki i Pedagogiki Chrześcijańskiej

\title{
Pojęcie matetyki we współczesnym dyskursie pedagogicznym i katechetycznym. Zarys problematyki
}

Autorem terminu „matetyka” (mathetica) jest pochodzący z Moraw, a przez szereg lat związany z wielkopolskim Lesznem, twórca nowożytnej pedagogiki, Jan Ámos Komenský (1592-1670)ํ․ Słowo matetyka utworzył on od

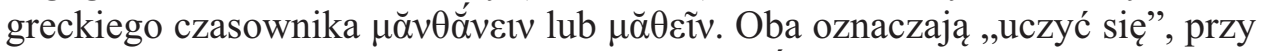
czym bezokolicznik czasu teraźniejszego $\mu \breve{\alpha} v \theta \ddot{\alpha} v \varepsilon ı v$ wskazuje na postępowanie linearne, trwające $\mathrm{w}$ czasie, natomiast bezokolicznik aorystu $\mu \breve{\alpha} \theta \varepsilon \tilde{v} v$ na czynność nagłą, momentalną i dokonaną. Zatem pierwszy z nich określa uczenie się jako proces, a drugi jako gwałtowne poznanie lub zrozumienie ${ }^{2}$. Oba

\footnotetext{
${ }^{1}$ Związek J.A. Komenskiego z Lesznem jest zdecydowanie niejednoznaczny. Rozpoczyna się w 1628 r., gdy do miasta przybyło około 1500 uchodźców religijnych z Czech i Moraw. Nowym osadnikom, reprezentującym Jednotę Braci Czeskich, przewodził właśnie J.A. Komenský. Pojawienie się uchodźców w Lesznie przyczyniło się do rozwoju przestrzennego, gospodarczego i kulturalnego miasta, które stało się siedzibą senioratu, a tym samym ,stolicą” Jednoty. Sprowadzono do Leszna archiwum, bibliotekę oraz drukarnię. Okazało się jednak, że J. A. Komenský nadużył gościnności i tolerancji Rzeczpospolitej. Skrycie dążył do przejęcia przez protestantów władzy w całej Polsce. Dlatego dostarczał Szwedom informacji na temat sytuacji w Rzeczpospolitej i współpracował w budowaniu przeciwko niej protestanckiej koalicji, złożonej z Szwecji, Anglii i Siedmiogrodu. W momencie szwedzkiego najazdu w 1655 r. J. A. Komenský otworzył bramy Leszna dla wojsk feldmarszałka Arvida Wittenberga. Nie reagował na szwedzkie gwałty i rabunki wobec katolickich współobywateli. Sytuacja odwróciła się pod koniec kwietnia 1656 r., kiedy oddziały Piotra Opalińskiego odbiły Leszno, zmuszając braci czeskich do ucieczki na południe. Niedługo później J. A. Komenský wydał broszurę, w której obrzucał Polaków obelgami i kłamliwie oskarżył o okrucieństwo względem protestantów w Lesznie. Faktem jest jedynie, że w czasie działań wojennych i pożaru miasta J. A. Komenský utracił swe cenne zbiory i rękopisy. Zmarł w Holandii w 1670 r.

${ }^{2}$ Por. P.O. Chott, Die Entwicklung des MATHETIK-Begriffs und seine Bedeutung für den Unterricht der (Grund-)Schule, „Pädagogisches Forum: unterrichten erziehen” 4 (1998), s. 392.
} 
znaczenia nie wykluczają się wzajemnie, lecz dopełniają. Tak tych czasowników używał Platon (427-347), który za najskuteczniejszy sposób uczenia się uważał metodę heurystyczną, przejętą od swego mistrza Sokratesa (469-399). Polega ona na takim stawianiu pytań przez nauczyciela, by skłonić ucznia do samodzielnego czynienia spostrzeżeń, dokonywania porównań i uogólnień oraz do wyciągania wniosków ${ }^{3}$. Można zatem w Platonie widzieć jednego z prekursorów matetyki, choć sam tego rzeczownika nie stosuje. Wcześniej tylko Protagoras (481-411), uważany za inspiratora europejskiej pedagogiki,

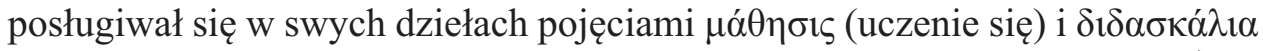
(nauczanie), nie przeprowadził jednak teoretycznej analizy tych terminów ${ }^{4}$.

Do spuścizny greckich filozofów nawiązał J. A. Komenský, tworząc pojęcie matetyki i definiując ją jako sztukę uczenia się: Mathetica est ars discendi ${ }^{5}$. Określenie znaczenia tego terminu pojawia się w wydanej dziesięć lat po śmierci autora książce Spicilegium didacticum, a nie - jak się niekiedy błędnie przyjmuje ${ }^{6}$ - w opublikowanym w 1657 roku dziele Didactica magna. W Wielkiej dydaktyce J. A. Komenský nie rozróżnia jeszcze wyraźnie sztuki nauczania i uczenia się. Na wstępie charakteryzuje wprawdzie dydaktykę jako ars docendi, w późniejszym wywodzie zdarza mu się jednak posługiwać pojęciem dydaktyki jako ars docendi ac discendi ${ }^{7}$. Dopiero w Spicilegium didacticum oddziela, a nawet przeciwstawia sobie sztukę nauczania (dydaktykę) i sztukę uczenia się (matetykę).

\section{Matetyka - zapomniana siostra dydaktyki}

Stworzony przez J.A. Komenskiego termin matetyka dość szybko popadł w zapomnienie w dyskursie pedagogicznym. Sztuka uczenia stała się częścią dydaktyki, która po dziś dzień jest definiowana jako ,jedna z podstawowych nauk pedagogicznych, której przedmiotem jest kształcenie ludzi, a więc wszel-

${ }^{3}$ Por. W. Witwicki, Platon jako pedagog, [w:] Z dziejów myśli pedagogicznej, red. B. Suchodolski, W. Okoń, Warszawa 1958, s. 64.

${ }^{4}$ Por. S. Wołoszyn, Pedagogika sofistów. Studium z dziejów antycznej kultury pedagogicznej, [w:] Z dziejów myśli pedagogicznej, s. 10-12.

5 J.A. Komenský, Spicilegium didacticum artium discendi ac docendi summam brevibus praeceptis exhibens. MSStis Cl. J.A. Comenii collectum et editum a C. V. N. Amstelodami typis Christophori Cunradi. Anno 1680. (red. Ján Kvačala). Nunc editum Rosenbergae: Typis Caroli Salva, 1895, s. 1, dostępny w Internecie w formie zdygitalizowanej: www.digitalniknihovna.cz/ mzk/uuid/uuid:211e1470-6168-11e4-8b87-001018b5eb5c (plný text), [dostęp 27 czerwca 2018].

${ }^{6}$ Taki błąd pojawia się na przykład w niemieckiej wersji popularnej internetowej encyklopedii Wikipedia. Zob. https://de.wikipedia.org/wiki/Mathetik [dostęp 28 czerwca 2018].

${ }^{7}$ Por. J.A. Komenský, Wielka dydaktyka, obejmująca całą sztukę nauczania wszystkiego wszystkich, wstępem i komentarzem opatrzył Henryk Wernic, Warszawa 1883, s. 4-8. 
kie nauczanie innych i uczenie się, niezależnie od tego, czy odbywa się ono w szkole, poza szkołą czy w codziennych sytuacjach życiowych"». Pojęcie matetyki pojawiło się na powrót $\mathrm{w}$ debacie pedagogicznej dopiero $\mathrm{w}$ drugiej połowie XX wieku, choć w polskiej literaturze przedmiotu nadal występuje sporadycznie $^{9}$. Wzrasta wprawdzie również w Polsce zainteresowanie samym aktem bądź procesem uczenia się, jednak dziedziny wiedzy, które się nim zajmują, nie są określane mianem matetyki, a zagadnienia, które wchodzą w jej zakres przedmiotowy, rozsiane są pośród różnych dyscyplin pedagogicznych i humanistycznych.

Powrót pojęcia matetyki do dyskursu pedagogicznego należy powiązać z powstaniem na University of Alabama fundacji na rzecz matetyki (Mathetics Foundation), która w 1962 roku rozpoczęła wydawanie „The Journal of Mathetics". Nie był to powrót spektakularny ani długotrwały. Ukazały się zaledwie dwa wydania tego periodyku, pierwszy w styczniu, a drugi w kwietniu tegoż roku. Spośród opublikowanych w nich artykułów najbliższy rozumieniu matetyki przez J. A. Komenskiego oraz jej współczesnym ujęciom był tekst redaktora naczelnego Thomasa F. Gilberta (1927-1995). Definiował on jednak matetykę bardziej „technologicznie" jako systematic application of reinforcement theory to the analysis and construction of complex behavior repertories which represent the mastery of subject matter ${ }^{10}$.

Autorem, który skutecznie wydobył pojęcie matetyki z otchłani zapomnienia, jest niemiecki pedagog Hartmut von Hentig (ur. 23 września 1925 r. w Poznaniu). W ekspertyzie opracowanej w 1983 roku dla okręgowego sądu administracyjnego we Frankfurcie nad Menem w sprawie o zatwierdzenie tzw. „wolnej szkoły”, H. von Hentig określa profil tejże szkoły jako „,zasadniczo matetyczny", po czym poświęca kilka stron na uzasadnienie swojej

${ }^{8}$ W. Okoń, Nowy stownik pedagogiczny, Warszawa ${ }^{3} 2001$, s. 82.

${ }^{9}$ Spośród kilku współczesnych leksykonów lub słowników pedagogicznych w języku polskim, jedynie w Stowniku pedagogicznym (por. W. Okoń, Słownik pedagogiczny, Warszawa ${ }^{5} 1992$, s. 120) i Nowym słowniku pedagogicznym Wincentego Okonia znaleźć można hasło „matetyka”. Autor definiuje ją jako naukę badającą „działalność ucznia w toku uczenia się. Niektórzy pedagodzy przeciwstawiają matetykę tej pedagogice, która dotąd była na ogół nastawiona na badanie zachowań nauczyciela w procesie nauczania” (W. Okoń, Nowy słownik pedagogiczny, s. 228). Hasło „matetyka" nie występuje natomiast w następujących publikacjach o charakterze encyklopedycznym: Encyklopedia pedagogiczna, red. W. Pomykało, Warszawa 1993; Pedagogika, red. B. Milerski, B. Śliwerski, Warszawa 2000; Encyklopedia pedagogiczna XXI wieku, t. 3, M-O, red. prowadzący E. Różycka ; autor t. 3 F. Adamski i in., Warszawa 2004; C. Kupisiewicz, M. Kupisiewicz, Słownik pedagogiczny, Warszawa 2009.

${ }^{10}$ T.F. Gilbert, Mathetics: The technology of education, „The Journal of Mathetics” 1 (1962), s. 9. Swoje poglądy T.F. Gilbert rozwijał i precyzował później w kolejnych publikacjach, np.: T.F. Gilbert, Some issues in mathetics. I saying what a subject matter is, „Performance Improvement” 2 (1969), s. 4-19; tenże, Mathetics: An explicit theory for the design of teaching programmes, London 1969. 
opinii i wyjaśnienie, czym jest matetyka ${ }^{11}$. Postrzega ją jako korektę „bezmyślnej i zdogmatyzowanej" zasady dydaktycznej, że uczenie się następuje poprzez instruowanie. W „wolnej szkole” zrezygnowano z systematycznego, nazbyt zracjonalizowanego i kolektywnego pouczania na rzecz indywidualnych potrzeb edukacyjnych oraz równowagi między kognitywnymi, społecznymi i afektywnymi procesami uczenia się dzieci. H. von Hentig uważa środki, jakie w swej koncepcji matetycznej wypracowała „wolna szkoła”, za pedagogicznie przekonujące. Są to przykładowo: podział na obszary uczenia się (a nie na przedmioty); integralność doświadczeń/uczenia się poprzez prowadzenie projektów; nawiązywanie do świata doświadczeń uczniów; zmieszanie dzieci $\mathrm{w}$ różnym wieku, różnego pochodzenia oraz wyposażonych w różnorodne duchowe, psychiczne i fizyczne predyspozycje; nieuleganie z góry przyjętym założeniom odnośnie do zdolności rozwojowych dziecka w określonym wieku, lub inaczej: sceptycyzm wobec konwencjonalnych schematów i norm psychologii rozwojowej i - co się z tym wiąże - odejście od testów wstępnych; poważne traktowanie życiowych problemów dziecka, które nakładają się na problemy z nauką. W pojedynczych sytuacjach oznacza to odroczenie nauki określonych przedmiotów czy umiejętności do czasu rozwiązania kwestii życiowych (dzięki temu jest jednak w ogóle możliwe ich opanowanie). Ważnym elementem koncepcji matetycznej jest także oddanie do dyspozycji dzieci całego wachlarza form uczenia się, które pozwala uczniom na wybór takiego sposobu uczenia się, który zapewni im sukces. W „wolnej szkole” zrezygnowano również ze stopni, wprowadzając w zamian „dziennik”, w którym odnotowuje się najważniejsze zaproponowane dzieciom doświadczenia oraz zapisuje przebieg rozwoju i uczenia się poszczególnych uczniów. Ważnym elementem koncepcji matetycznej są także nauczyciele, wychowawcy i rodzice. Ich zaangażowanie nadal jest niezbędne, zakłada się ich pomoc, gdy dziecko ma kłopoty w czasie samoregulowanego uczenia się ${ }^{12}$.

$\mathrm{W}$ „wolnej szkole” pierwszeństwo mają jednak te formy uczenia się, w których dzieci samodzielnie i możliwie aktywnie przyswajają sobie wiedzę i nabywają umiejętności. W tych procesach są wykorzystywane wszystkie zmysły. By uczenie się było satysfakcjonujące i sensowne, decydujące jest powiązanie nowych wiadomości i umiejętności z jakimś znanym już uczniowi kontekstem. Równie istotne jest, by był to temat intrygujący i ważny dla dziecięcego świata. Nic tak nie wzmaga motywacji człowieka do uczenia się jak ciekawość. Wypływa ona z osobistych doświadczeń i czyni uczenie się skutecznym i trwałym. Obserwując codzienność „wolnej szkoły”, H. von

${ }^{11}$ Dwa lata później ekspertyza ta została opublikowane drukiem. Tym samym pojęcie matetyki zostało wprowadzone do dyskusji pedagogicznej. Por. H. von Hentig, Wie frei sind Freie Schulen? Gutachten für ein Verwaltungsgericht, Stuttgart 1985.

${ }^{12}$ Por. tamże, s. 80 n. 
Hentig opisywał przykładowe aktywności, które powodują, że uczenie się wyrasta z zainteresowań dzieci. Przechodzą one swobodnie od rozmowy z innym dzieckiem do wspólnej zabawy, nierzadko samodzielnie planując i wykonując zabawkę. Idą na zakupy i natrafiają przy okazji na problemy z liczeniem. Dołączają do grupy, która zamierza coś pasjonującego, spierają się o obejrzane programy telewizyjne, słuchają muzyki. W ten sposób zdobywają doświadczenia. U uczniów powstają nowe zainteresowania, stwarzając sposobności do samodzielnego uczenia się. Czasem pojawiają się również pytania i problemy, które wymagają pomocy innego dziecka lub dorosłego. Tak właśnie uczniowie konfrontują się z różnorodnymi aspektami świata, a „suche przedmioty” zostają napełnione życiem. Pozornie nieprzydatna wiedza zyskuje sens, cel i jakość, które obrazuje bezpośrednia sytuacja. Na przykład matematyka staje się zrozumiała, jeśli jest powiązana z codziennym życiem. W „wolnej szkole” prawie każdy temat jest opracowany na podstawie przykładu zaczerpniętego z codzienności, konkluduje H. von Hentig ${ }^{13}$.

Autor w swej opinii zauważa ponadto, że idee, które on określa mianem matetyki, nie są absolutną nowością, lecz leżą u podstaw znanych już systemów pedagogicznych. Za klasyczny przykład matetyki H. von Hentig uważa pedagogikę Marii Montessori, która wprowadzała dzieci w świat kunsztownie przygotowanych możliwości uczenia się i pozostawiała uczniom wybór sposobu, w jaki zaspokoją oni swoją potrzebę poznawania. Pewne elementy matetyki autor omawianej ekspertyzy widzi również w pedagogice Célestina Freineta oraz szkole waldorfskiej Rudolfa Steinera. Polegają one w gruncie rzeczy na tym, że sytuacje i treści nauczania zorganizowane są w ścisłym i pieczołowicie dopracowanym porządku, przechodząc od tego, co zmysłowe i realne, do tego, co teoretyczne i abstrakcyjne. Od tych już nienowych, lecz wypróbowanych i - wskutek rozczarowania współczesną szkołą publiczną - czasem przecenianych koncepcji, matetyka (pedagogika „wolnej szkoły”) odróżnia się zasadniczo większym radykalizmem w poważnym traktowaniu potrzeb edukacyjnych dzieci oraz w stawianiu na równi procesów społecznych, fizyczno-zmysłowych i kognitywnych w uczeniu się ${ }^{14}$.

Matetyka nie oznacza bynajmniej samowoli lub dowolności. Wręcz przeciwnie, zdaniem H. von Hentiga zakłada porządek przestrzeni doświadczeń. Akcenty w pracy nauczyciela przesuwają się zatem w stronę zorganizowania uczniom okazji do uczenia się. W tej przestrzeni nauczyciel nie przestaje udzielać informacji, wyjaśniać, opowiadać, pokazywać czy doradzać. Czyni to jedynie bez intencji zatrzymania dziecka na jedynie słusznej, czyli przez niego ustalonej ścieżce uczenia się. Matetyka rozpatruje szkolne uczenie się z punk-

13 Tamże, s. 85n.

14 Tamże, s. 80. 
tu widzenia ucznia i charakteryzuje relację między nauczycielem a uczniem jako symetryczną i pozbawioną dominacji. Nauczyciel nie jest tu hegemonem, lecz służącym pomocą doradcą. Z powyższego wynika, że między niezłym dydaktykiem a dobrym matetykiem nie ma praktycznie aż tak wielkiej różnicy. Dobra matetyka nie wyklucza dobrej dydaktyki, lecz ogranicza jej znaczenie. Relatywizuje dydaktykę zorientowaną na cele nauczania (ponieważ dokładne sprawdzenie osiągniętych celów jest niejednokrotnie niemożliwe według obiektywnych kryteriów) oraz sprzeciwia się wszelkiej dydaktyce skoncentrowanej jedynie na czynnościach nauczyciela ${ }^{15}$.

W miarę rozwoju tzw. pedagogiki reformy pojawił się alternatywny paradygmat edukacji, odciskający stopniowo coraz większe piętno na roli i zadaniach nauczyciela. Bywał on nazywany ,subiektywnym modelem dydaktyki" "16, jednak w celu uniknięcia nieporozumień z czasem na jego określenie wprowadzono pojęcie matetyki. Alternatywa matetyczna polega w tym wypadku na ukierunkowaniu zainteresowań naukowych w stronę wyjaśnienia - zachodzących w czasie zajęć lekcyjnych (i pozalekcyjnych) - procesów uczenia się z akcentem na punkt widzenia uczniów ${ }^{17}$. Na gruncie rozważań pedagogiki reformy, wsparty osiągnięciami edukacji konstruktywistyczno-emancypacyjnej, psychologii wychowawczej i psychologii uczenia się oraz ostatnio odkryciami z zakresu neuropsychologii, psychoneuroimmunologii (PNI) i neuroedukacji, model matetyki rozwija się obecnie w kierunku oddania pierwszeństwa uczącym się jednostkom w coraz liczniejszych obszarach i sytuacjach edukacyjnych. Matetyka „charakteryzuje się konsolidacją wiedzy kondycjonalnej i metakognitywnej, służącej weryfikacji strategii uczenia się" oraz nakłada stopniowo coraz większą odpowiedzialność na samych uczniów, „domagając się od nich wysiłku i osiągnięćc"18.

Rozwój matetyki następuje zatem nie tyle interdyscyplinarnie, co transdyscyplinarnie. Interdyscyplinarność jest osadzona w przestrzeni dwuwymiarowej, natomiast nowe, obejmujące wiele obszarów, dziedziny badań nie mogą być postrzegane jedynie jako grupa lub prosta kombinacja kilku spokrewnionych dyscyplin naukowych. Chodzi w nich o wiele bardziej o zbudowanie własnej konceptualnej struktury, opartej wprawdzie na osiągnięciach licznych dyscyplin, ale przekraczającej granice nauk przyrodniczych, społecznych i humanistycznych. Model transdyscyplinarny domaga się osadzenia w przestrzeni trójwymiarowej, w której na fundamencie złożonym $\mathrm{z}$ wielu różno-

15 Tamże, s. 85 .

16 Por. E. Kösel, Die Modellierung von Lernwelten, Elztal-Dallau 1993, s. 14.

${ }^{17}$ Por. P.O. Chott, Die Entwicklung des MATHETIK-Begriffs, art. cyt., s. 392.

18 M.A. Anton, Erziehen und Sich-bilden - Lehren und Lernen - Didaktik und Mathetik, w: „Lernwelten“ 2 (2003), s. 76. 
rodnych obszarów nauki buduje się kolejne poziomy odrębnej i samodzielnej dziedziny wiedzy. W przypadku matetyki można to zilustrować graficznie następująco:

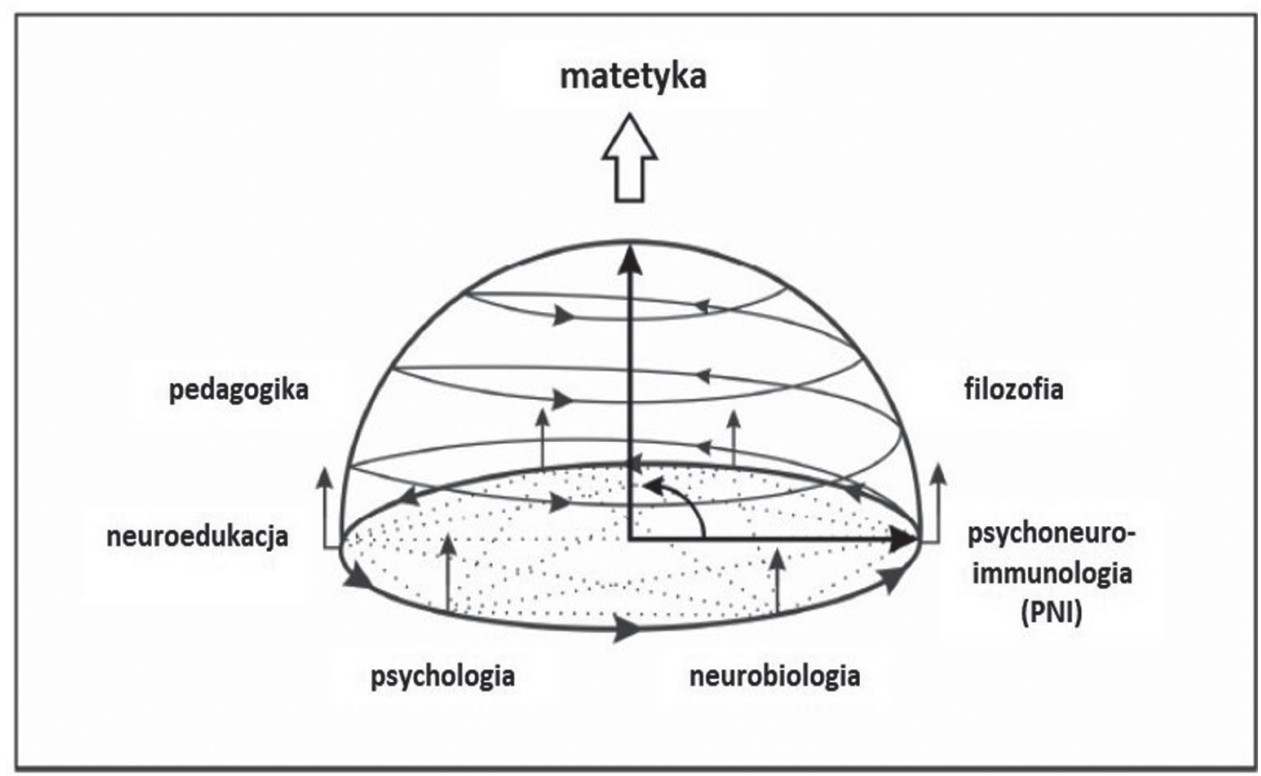

Schemat 1: Matetyka w ujęciu transdyscyplinarnym ${ }^{19}$

Specyfikę matetyki oddaje również kolejny schemat, w którym ukazane zostały zróżnicowane źródła i linie rozwojowe teorii dydaktycznych i matetycznych oraz wynikające z nich konsekwencje dla procesu uczenia się i nauczania.

${ }^{19}$ Por. H. Koizumi, Wie funktioniert das Gehirn?, Paris 2003, s. 113n. 
Linie rozwoju w budowaniu teorii pedagogicznych i konstrukcji dydaktycznych

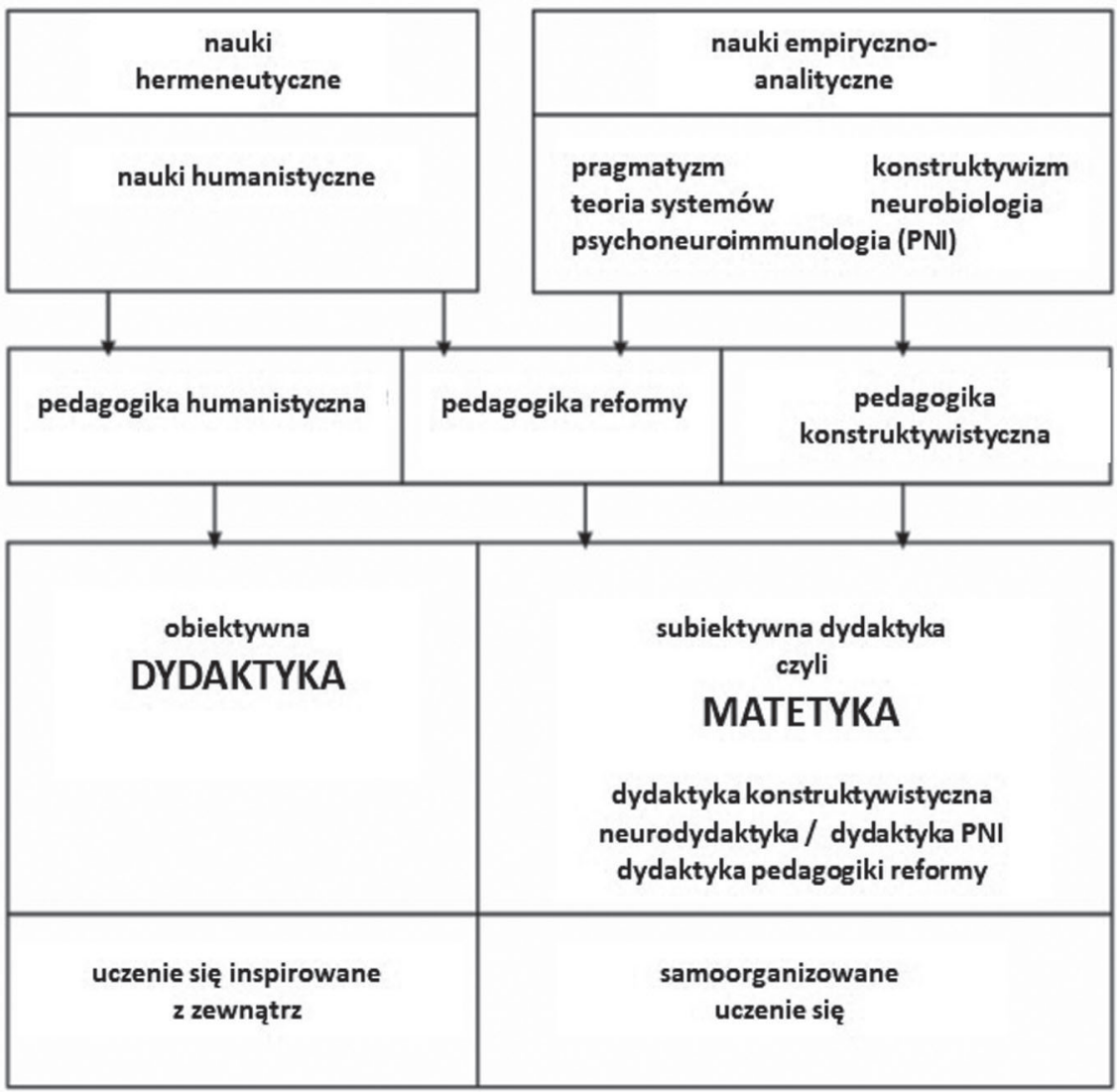

Schemat 2. Linie rozwoju teorii pedagogicznych i dydaktycznych ${ }^{20}$

Podsumowując tę cześć rozważań, matetyka zakłada konstruktywistyczne pojmowanie uczenia się, rozumianego jako dynamiczny, autopoietyczny (samoorganizujący się) proces, podczas którego człowiek tworzy swą własną rzeczywistość ${ }^{21}$. Matetyka uwzględnia ponadto integralny sposób patrzenia na

20 Por. W.D. Kohlberg, T. Unseld, Mathetik. Mathetik des E-Learnings (s. 1-34); Mathetics. Mathetics of E-Learning (s. 35-64); Mathétique. Mathétique du E-Learning (s. 65-96), Osnabrück 2007, s. 3, 37, 67.

${ }^{21}$ Por. P.O. Chott, Die Entwicklung des MATHETIK-Begriffs, art. cyt., s. 391. 
ucznia oraz postrzega przebieg uczenia się z jego perspektywy. W związku z tym widzi jego działanie w kontekście jego całej osobowości i rozpoznaje jego doświadczenia $z$ sobą samym i otaczającym światem jako integralnie i kompleksowo powiązane. W konsekwencji oznacza to, że nauczanie jest rozumiane jako uporządkowana i wyczerpująca oferta skierowana do ucznia, w której znaczącą rolę odgrywa nie tylko przekaz treści, lecz również płaszczyzna relacji, co sprawia, że w procesie uczenia się dochodzą do głosu również emocje, motywacje i wola uczniów, a nie tylko ich rozum.

\section{Matetyka jako przedmiot zainteresowania pedagogiki religii i katechetyki}

Zastrzeżenia dotyczące niewystarczalności współczesnego systemu edukacji w kontekście zachodzących zmian społeczno-kulturowych dotyczą w równej mierze religijnego uczenia się i nauczania, zarówno w środowisku szkolnym, jak i parafialnym. Stąd pojawiły się próby zaadaptowania pojęcia matetyki do refleksji religijnopedagogicznej. Poszły one w dwóch kierunkach. Pierwsza próba miała miejsce w latach osiemdziesiątych dwudziestego wieku w Holandii za sprawą protestanckiego pastoralisty Gijsberta Dingemansa (ur. 1933), który wywodzi termin matetyka z teologii uczenia się zawartej w Nowym Testamencie. Jego zdaniem w matetyce - w jej pierwotnym znaczeniu - chodzi o odpowiedź na dwa podstawowe pytania: „Jak ludzie stają się uczniami Jezusa? W jaki sposób uczą się wierzyć?"22 . Autor podejmuje zatem polemikę z tradycyjnym pojmowaniem katechetyki, która za swój punkt wyjścia obiera nauczanie wiary Kościoła. W myśl tej zasady należy najpierw stwierdzić, o co chodzi w doktrynie, by następnie przywołując na pomoc dydaktykę (lub po prostu zdrowy rozsądek), ,przekazać” tak zarysowaną wiarę uczniom. W swej koncepcji G. Dingemans za punkt wyjścia przyjmuje nie tyle prawdy, które należy przekazać, co wspólnotę wiary tych, którzy razem chcą stać się uczniami Pana. Jest to więc - jak sam przyznaje - katechetyka „postawiona na głowie"23.

Autor podkreśla dialogiczny i osobowy charakter nauczania i uczenia się w pierwotnej, judeomesjanistycznej wspólnocie chrześcijańskiej. Nie rozwija jednak tego historycznego wątku, w trakcie wywodu zaczyna natomiast utożsamiać pojęcie uczenia się z naśladowaniem. Tutaj tkwi najsłabsza część jego argumentacji. Autor buduje całą swoją koncepcję katechetyki na idei pierwot-

${ }^{22}$ G.D.J. Dingemans, In de leerschool van het geloof. Mathetiek en vakdidactiek voor catechese en kerkelijk vormingswerk (Handboek praktische theologie, Band 3), Kampen 1986, s. 15.

${ }^{23}$ Por. tamże, s. 14. 
nego Kościoła, rozumianego jako ucząca się wspólnota. Widać jednak wyraźnie, że „uczenie się” nie jest dla niego (poza kontekstem „naśladowania”) pojęciem teologicznym, lecz bardziej antropologicznym. Teza ta znajduje swoje uzasadnienie w stwierdzeniach, że uczenie się w sposób naturalny należy do wspólnoty chrześcijańskiej, ponieważ jest podstawową funkcją każdego człowieka i każdej ludzkiej społeczności. De facto G. Dingemans reprezentuje zatem stanowisko zbliżone do współczesnej, odwołującej się bezpośrednio do Martina Lutra, ewangelickiej pedagogiki religijnej24.

Źródła praktyki uczenia się i nauczania pierwotnego Kościoła dostrzega autor w głoszeniu Dobrej Nowiny przez Jezusa Chrystusa, które zakorzenione jest $\mathrm{w}$ tradycji żydowskiej. Nie bez chrześcijańsko-dogmatycznego przerysowania tego stanu rzeczy, stwierdza jednak: „Nasza konkluzja brzmi, że nauczanie Jezusa jest zbliżone do nauczania rabinów, ale istotna różnica tkwi w autorytecie, którym cieszy się Jezus. Jego słowa mają ładunek i siłę samego Boga. Przenikają ludzi do szpiku kości”"25. W dalszym wywodzie judaizm zostaje zdegradowany wyłącznie do ,ludzkiego nauczania”, co przeczy jednak judaistycznemu samozrozumieniu, jak je ujmuje choćby - cytowany notabene przez G. Dingemansa - żydowski pedagog Ido Abram (1940-2019): „Bóg jest z tym, który się uczy. Między jednostką a Bogiem w judaizmie znajduje się tylko proces uczenia się, a nie jakiś pośrednik, którego trzeba by o coś prosić. Uczenie się nie jest jedynie kwestią rozumu, lecz także drogą religijnego doświadczenia" 26 . Trudno zatem redukować judaizm do czysto ludzkiego nauczania, skoro w procesie uczenia się uczestniczy sam Bóg, a dzięki temu możliwe staje się doświadczenie gruntownej przemiany ludzkiego życia.

Nieścisłości w rozumieniu pojęcia uczenia się widać także w późniejszej twórczości G. Dingemansa ${ }^{27}$. Niezmiennie dostrzega on bliskość chrześcijańskiej matetyki z judaistycznym rozumieniem uczenia się, jednak jego konstatacje pozostają dość powierzchowne. Wciąż brakuje rozwinięcia matetyki z punktu widzenia teologii Nowego Testamentu i tradycji judaistycznej. Natomiast odpowiedź na pytanie, czym właściwie jest uczenie się, G. Dingemans pozostawia psychologii.

W podobnym duchu wypowiada się niemiecki pedagog religii Norbert Mette (ur. 1946), który postuluje wypracowanie matetyki wiary w oparciu

${ }^{24}$ Por. G.D.J. Dingemans, In de leerschool van het geloof, s. 169n.

${ }^{25}$ „Onze conclusie is, dat het onderricht van Jezus dicht bij dat van de rabbijnen staat, maar dat het verschil duidelijk wordt in het gezag, dat vaan Jezus uitstraalt. Zijn wooorden hebben de lading en de kracht van God zelf. Ze raken mensen tot op het bot". Tamże, s. 168.

${ }^{26}$ I. Abram, Judentum und permanentes Lernen, [w:] Lehren und Lernen in jüdisch-christlicher Tradition. Erfahrungen aus den Niederlanden, red. U.F.W. Bauer, A.H. Wöhle, Knesebeck 1995, s. 47-59, 48 .

${ }^{27}$ G.D.J. Dingemans, Manieren van doen. Inleiding tot de studie van de praktische theologie, Kampen 1996, s. 206. 
o osiągnięcia psychologii rozwojowej i psychologii uczenia się. Proponuje również uzupełnienie refleksji o elementy teologii wyzwolenia. Matetyka jest dla N. Mettego badaniem „uwarunkowań i procesów wspólnego uczenia się, rozumianego jako transformacja zarówno indywidulanej świadomości i zachowania, jak i kolektywnych struktur" 28 . Powołując się na G. Dingemansa, N. Mette uznaje prymat matetyki nad klasyczną dydaktyką, która w przeszłości stawiała pytanie jedynie o skuteczny przekaz prawd wiary. Zdaje się przy tym nie zauważać, że G. Dingemans odciął się wprawdzie od tradycyjnej katechetyki, lecz w żadnym razie nie zrezygnował z konwencjonalnej dydaktyki. Jednocześnie N. Mette przesuwa znaczenie pojęcia dydaktyki niebezpiecznie blisko metodyki, umieszczając matetykę w granicach pedagogiki religijnej ukierunkowanej na wspólne działanie i aktywność wszystkich podmiotów uczestniczących w procesie uczenia się. Taka lokalizacja matetyki wydaje się jednak nieuzasadnionym zawężeniem.

Druga propozycja przeniesienia matetyki na grunt katechetyki i pedagogiki religijnej została sformułowane przez H. von Hentiga w książce Glaube. Fluchten aus der Aufklärung. Barwnym językiem i z publicystycznym zacięciem odpowiada on na pięć postawionych we wstępie pytań:

1. Czy wiara jest dla większości współczesnych ludzi sprawą poważną i świadomą, dającą prawdziwą nadzieję, czy też tak obojętną, jak to się od przynajmniej dwustu lat przyjmuje?

2. Jakie powody mogą skłonić ludzi ku temu, by troszczyć się o rozwój swej wiary lub by ostatecznie jej się pozbyć wraz z pozostałościami w naszym języku i wyobrażeniach, postawach i instytucjach?

3. Co to jest „wiara” i co to znaczy, „wierzyć”? Czy możliwe jest porozumienie w tym zakresie między wierzącymi, niewierzącymi i metodycznymi sceptykami?

4. Jak można zdobyć wiarę? I czy można jej (kogoś) nauczyć?

5. Jaka wiara ma szansę pomóc $\mathrm{w}$ zamęcie, lęku, cynizmie i rezygnacji, które ogarniają ludzi w obliczu zracjonalizowanego świata i jego bezsensowności: w obliczu bezsensownej przemocy, bezsensownego postępu, bezsensowego pośpiechu, bezsensownego rozłamu, bezsensownej integracji, bezsensownej fascynacji końcem wszystkich rzeczy?

Autor przyznaje, że odpowiedź na pierwsze pytanie przekracza jego możliwości, ponieważ wymaga badań empirycznych. Jednocześnie zauważa, że przeprowadzenie rzetelnych studiów na ten temat staje się możliwe dopiero po ustaleniu w miarę zgodnej odpowiedzi na kolejne dwa pytania: co to znaczy

${ }^{28}$ N. Mette, Religionspädagogik, Düsseldorf ${ }^{2} 2000$, s. 238 n. 
„wierzyć” i co prowokuje ludzi do wiary bądź niewiary. Te kwestie H. von Hentig podejmuje, odwołując się do myśli wybranych filozofów, pomija natomiast odpowiedzi teologiczne. Dopiero dwa ostatnie pytania dotyczą wprost matetyki i zostają potraktowane przez autora w perspektywie pedagogicznej29.

W swych diagnozach autor wskazuje zjawiska charakterystyczne dla współczesnej sytuacji religii. Największe zagrożenie widzi w jej oderwaniu od życia codziennego. Religia - administrowana i prezentowana przez wąską grupę ludzi - należy do peryferii egzystencji, jest zjawiskiem wyjątkowym, ograniczonym w najlepszym wypadku do niedzielnego lub świątecznego nabożeństwa, lekcji religii w szkole oraz chrztu, ślubu i pogrzebu. Można powiedzieć, że przyczyną takiego stanu rzeczy jest „odczarowanie” świata, które rozpoczęło się wraz z racjonalistycznymi prądami oświecenia. Osoby ,zawodowo" zajmujące się głoszeniem i nauczaniem wiary nie sprostały wyzwaniu i poszły za tym nurtem, doprowadzając do duchowego osłabienia wiary, do rozwodnienia ducha. Taka swego rodzaju wiara bez Boga (albo przynajmniej przy Jego nikłym udziale) nie ma siły przyciągania ani przekonywania. W dalszym wywodzie $H$. von Hentig analizuje przyczyny, które utrudniają przyjęcie wiary. Ilustruje je również licznymi przykładami. W jego opinii ludzie odrzucają wiarę, gdy jej piękno zostaje zaciemnione poprzez ${ }^{30}$ :

1. Hermetyczny język nauczania. Brzmi on tym donośniej, im bardziej jest pusty. Chodzi o język, za którym nie stoi osobiste doświadczenie wiary, który maskuje jedynie własną bezmyślność, nawyki i przyzwyczajenia głoszących wiarę.

2. Akcentowanie abstrakcyjnego nauczania na temat wiary. Wiąże się ono z oderwanym od życia językiem.

3. Moralizowanie. $\mathrm{W}$ tym wypadku nie chodzi w pierwszym rzędzie o podejrzenie, że religijność jest źródłem obłudy, a pobożność maskowaniem własnych słabości, a nawet moralnego zepsucia. Nie idzie również o to, że „oświecone” lub liberalnie nastawione osoby odrzuca pewność siebie, z jaką Kościoły i kapłani łączą wiarę, której nauczają, z nakazami moralnymi z jednej i groźbami kary z drugiej strony. Zdaniem autora nie byłoby to nawet najgorsze, oznaczałoby bowiem, że w obojętnym lub kapryśnym świecie istnieje jeszcze coś bezwarunkowego, jakiś nieprzekupny autorytet, który mógłby przyciągnąc ludzi do wiary. Największe zagrożenie moralizowania leży jednak według H. von Hentiga w tym, że religia zostaje zawężona do przestrzegania

${ }^{29}$ Por. H. von Hentig, Glaube. Fluchten aus der Aufklärung, Düsseldorf 1992, szczególnie s. $66-122$.

${ }^{30}$ Por. tamże, s. 81-107. 
nakazów i zakazów, a Bóg ograniczony do ostatecznej instancji decydującej o dobru i złu lub egzekwującej naruszenie prawa. Taki „zmoralizowany" Bóg staje się Bogiem oswojonym, udomowionym, czyli w efekcie niezdolnym, by nadać sens ludzkiej egzystencji. W obliczu przeciwności losu, cierpienia lub śmierci wiara oparta jedynie na etyce musi zostać wcześniej czy później odrzucona.

4. Naciągane teologizowanie. H. von Hentig odróżnia tutaj „mówienie o Bogu od wyjaśniania Boga. Pierwsze wyraża się w metaforach, obrazach i opowiadaniach. Wyrasta $z$ osobistego doświadczenia i może ułatwić innym przyjęcie wiary. Drugie przeciwnie. Teologizowanie, polegające na odartym $\mathrm{z}$ tajemnicy interpretowaniu Boga, utrudnia akceptację wiary.

5. Soul engineering. Najwięcej do zarzucenia w tym zakresie ma $\mathrm{H}$. von Hentig dydaktyce (niemieckojęzycznej) katechezy. Czasopisma fachowe i plany nauczania zajmują się bardziej takimi tematami, jak miłość i przyjaźń, ,ja" i tożsamość, media i przemoc, ochrona środowiska i uchodźcy niż religią. Programy (ewangelickich) sympozjów przepełnione są kłopotami w relacjach międzyludzkich, problemami międzypokoleniowymi i tożsamościowymi. Zawsze z dodatkiem odrobiny teologii. To, czego przy takich okazjach dowiedzą się uczestnicy lub czytelnicy, jest w opinii H. von Hentiga niewątpliwie pożyteczne. Myli się jednak ten, kto sądzi, że taką tematyką otworzy młodym ludziom drogę do wiary. W jeszcze większym błędzie jest ten, kto w owej ,inżynierii duszy" widzi przedsmak Królestwa Bożego. Dla H. von Hentiga jednak to nic innego jak ,metafizyczne wycieńczenie”.

6. Apokaliptyczne, racjonalistyczne i trywialne religie zastępcze. Ich pojawienie się jest związane ze zjawiskami, które zagrażają istnieniu znanego nam świata: niesprawiedliwością społeczną, wyścigiem zbrojeń i przemocą, zanieczyszczeniem środowiska naturalnego. Wprawdzie końcem świata straszono bezbożnych i niewierzących od zarania istnienia religii, jednak w obecnej dobie rolę proroków zniszczenia przejęli autorzy naukowych prognoz. Kościoły chrześcijańskie wobec tych zagrożeń zajęły zdaniem $\mathrm{H}$. von Hentiga stanowisko wyważone, odważne i racjonalne. Nie poprzestają przy tym jedynie na ostrzeganiu świata przed samozagładą, lecz proponują chrześcijańskie środki zaradcze, takie jak służba, ofiarność, umiarkowanie, wytrwałość i odwaga do zmian. Są jednak tacy, którym to nie wystarcza, dla których wspomniane propozycje są albo zbyt mało radykalne, albo za mało racjonalne. Dlatego pojawiają się „religie zastępcze”, głoszące, że mają lekarstwo na wszelkie bolączki tego świata. Według H. von Hentiga linia podziału przestała już w związku z tym przebiegać między na- 
uką a wiarą, lecz wyznacza ją teraz granica między praktycznymi, możliwymi do uzasadnienia i instytucjonalnymi drogami zbawienia (w tradycyjnych Kościołach chrześcijańskich) a trudnymi do ustalenia, niemożliwymi do uogólnienia i zinstytucjonalizowania osobistymi pokusami i nadziejami, doświadczeniami granicznymi lub wymarłymi formami oświeceniowego racjonalizmu.

7. Trudne formuły wiary chrześcijańskich Kościołów. Są one zniechęcające dla rozumu, chronią przed niezbędnymi dla rozwoju próbami wiary, co w efekcie powoduje jej osłabienie. Powiązane jest to niewątpliwie z niedostępnym językiem, ale $\mathrm{H}$. von Hentigowi chodzi o coś więcej. Obecne sformułowanie prawd wiary rodziło się bowiem niejednokrotnie jako odpowiedź na zagrożenia, jako teologiczne uzupełnienie bądź dogmatyczne zaprzeczenie agnostycyzmu, racjonalizmu czy odkryć naukowych. Zaplanowany przez Boga porządek świata stał się bastionem przeciwko materializmowi, hedonizmowi, utylitaryzmowi lub laickim drogom zbawienia. Przekazane wyznanie wiary, wprowadzenie w życie wspólnotowe, celebracja liturgiczna stanowiły odpowiedź na samotność, pustkę czy rozdarcie duszy jednostki. To wszystko były narzędzia walki, które stały się jednocześnie przyczynami obecnego kryzysu. Należałoby się wobec tego zastanowić, które z nich są aktualnie jedynie atrapą tajemnicy, pozostałością jakiejś dawno rozwiązanej trudności, historycznym nieporozumieniem lub środkiem zastraszenia. W przeciwnym razie prawdy chrześcijańskiej wiary w ich obecnym kształcie nie będą wystarczająco atrakcyjną ofertą dla ludzi współczesnych, którzy zmagają się ze światopoglądowym pluralizmem, rosnącym dobrobytem, nadmiarem osobistej wolności i trendem do samorealizacji, a przede wszystkim z praktyczną niewiarą.

Z powyższych analiz $H$. von Hentig wyciąga wniosek, że uczenie się wiary jest procesem o wiele bardziej elementarnym i kompleksowym niż zwykło się przyjmować, czymś więcej niż wskazania (udzielane osobom lub instytucjom) i polecenia (dotyczące treści lub metod). Autor podkreśla, że nie jest dydaktykiem nauczania religii ani katechetą, nie ma też żadnego teologicznego przygotowania. To czyni go bezstronnym. Dlatego podejmuje się - wolny od profesjonalnych kompetencji i zależności - sformułowania własnego konceptu dla procesu ,uczenia się wiary”, szkicu, który będzie obejmował całość i mimo wszystko pozostanie zwięzły. Tego właśnie nie potrafią profesjonaliści, ponieważ wiedza skłania ich do szukania trudności lub skrupulatnego ograniczania tematu.

Zanim H. von Hentig przedstawi swoją koncepcję, czyni kilka zastrzeżeń. Jego zamiar opiera się - bardziej niż wszelkie jego dotychczasowe próby pe- 
dagogiczne - na matetyce (sztuce, która umożliwia skuteczne uczenie się), a nie na dydaktyce (sztuce umożliwiającej efektywne nauczanie). Przypomina, że dobra matetyka nie wyklucza dobrej dydaktyki, ogranicza jednak jej znaczenie. „Nauczyciel” pozostaje niezbędny, pełni jednak odmienną niż dotychczas funkcję: budzi idee, stawia pytania i problemy, konstruuje zadania oraz warunki do uczenia się; pomaga, chwali, stawia opór, pokazuje, „co można móc".

\section{Praktyczne implikacje matetyki wiary}

W prezentowanej koncepcji matetyki wiary autorstwa H. von Hentiga nie chodzi o stworzenie jakiegoś ramowego programu nauczania, ale o wiele bardziej o paletę poglądów i postaw, które powinien posiadać człowiek odpowiedzialny za proces uczenia się wiary. Ta paleta jest wprawdzie uporządkowana, nie rości sobie jednak pretensji do systematyki i nie jest pozbawiona luk. Dlatego poszczególne elementy koncepcji zostały przez H. von Hentiga ponumerowane. W numeracji tej idzie jednak bardziej o wyliczenie i pewną swobodę kompozycji niż o kolejność. Jako człowiek praktyczny H. von Hentig wyobraża sobie również czytelnika swych propozycji i formułuje je w taki sposób, by można było dość łatwo przełożyć je na określone działania w szkole czy w katechezie parafialnej (np. sakramentalnej). To właśnie w tych środowiskach uczenie się wiary wymaga namysłu i nowego planu. W rodzinie przeciwnie, dokonuje się ono - i zapewne $\mathrm{z}$ lepszym skutkiem, gdy właśnie tak - w sposób spontaniczny i niezaplanowany. Na koniec autor podkreśla, że tego typu przemyśleń nie można oderwać od konkretnej wiary, którą się samemu wyznaje. Dlatego poniższe refleksje dotyczą uczenia się wiary chrześcijańskiej, a nie jakiejkolwiek.

Po tych wyjaśnieniach $\mathrm{H}$. von Hentig przechodzi do zaprezentowania dziesięciu myśli na temat matetyki chrześcijańskiej wiary ${ }^{31}$.

1. Z uczeniem się wiary jest podobnie jak z uczeniem się myślenia: „wierzy się” i „myśli się”, zanim zaczyna się tego „uczyć”. Jeśli ktoś chce w tym pomóc innym, szczególnie młodym, musi najpierw pozwolić im sobie o tym opowiedzieć i uważnie słuchać, by nie przeoczyć wiary, która ,już jest” lub właśnie szykuje się do „przełomu”. Jeśli coś ,,już jest”, może się rozpaść, gdy nie jest potwierdzane lub wspierane przez stawianie wymagań.

\footnotetext{
${ }^{31}$ Por. H. von Hentig, Glaube, s. 108-122.
} 
2. We współczesnym świecie istnieje zapewne więcej obojętności religijnej niż jej trudnych sióstr - niewiary i zwątpienia. Jeśli gdzieś brakuje (świadomej) wiary, tam pouczanie nic nie pomoże. Wówczas trzeba korzystać z matetyki - z całym jej poszukiwaniem okazji, sposobności i wyzwań oraz cierpliwym czekaniem. Cierpliwości domaga się matetyka wiary w sposób szczególnie kategoryczny.

3. Kto chce pomóc wierzyć, musi brać na serio niewiarę ludzi. Powraca tu wołanie ojca chłopca opętanego przez ducha nieczystego: Wierzę, zaradź memu niedowiarstwu! (Mk 9,24). Poważne potraktowanie niewiary dokonuje się poprzez wystawienie własnej wiary na zarzuty, niezrozumienie i niechęć człowieka niewierzącego. Dzieje się to również przez surowe sprawdzanie własnego sposobu mówienia oraz translację słów, figur myślowych i obrazów, które zostały wypracowane w tradycji judeochrześcijańskiej, na świecki język i obrazy. Czyni to wiarę nie tylko bardziej przekonującą wobec świata, ale stanowi również wysiłek pożyteczny dla wiary samego wierzącego, który próbuje dotrzeć z treściami religijnymi do sobie współczesnych. Demitologizacja to nie tylko metoda pracy określonej szkoły teologicznej, lecz również stały proces właściwy wierze.

4. Zatrzymanie się jedynie na refleksji na temat wiary to zbyt mało, by przygotować jej drogę. Na płaszczyźnie niewiary lub obojętności nie napotyka się bowiem ani mniej sprzeczności, ani mniej ludzkich dramatów niż na obszarze wiary. Nie przewyższa też ona obu pierwszych, gdy chodzi o zwątpienie lub zaufanie, ponieważ w gruncie rzeczy wiara jest ciągiem wątpienia. Tym, co charakteryzuje człowieka wierzącego, jest jednak większa szczerość - przyznanie się przed sobą, że nie potrafi konstrukcjami swego rozumu ani pojąć świata, ani podołać życiu. Wiara w obecnej rzeczywistości, w znacznej mierze tworzonej i interpretowanej przez ludzi, jest zatem dostrzeżeniem ograniczeń oświeceniowego myślenia i postrzegania świata. Można je lepiej zrozumieć na przykładzie pięciu fundamentalnych doświadczeń (nie są to jeszcze doświadczenia wprost związane $\mathrm{z}$ wiarą). Pierwszym z nich jest śmierć, kolejnymi są doświadczenia winy, piękna, szczęścia i świadomość istnienia na ziemi innych istot, które przestrzegają człowieka przed mierzeniem wszystkiego swoją własną miarą.

5. Ponieważ niemożliwe jest wyprodukowanie wiary i tym bardziej nie można sztucznie wywołać doświadczenia wiary, a jednocześnie religia jest powszechnie praktykowana, należy dokonać ważnego dla niniejszych rozważań rozróżnienia. Otóż zdaniem $\mathrm{H}$. von Hentiga religie są obiektywizacją wiary, jej formami, które przyjmowała w historii, wiara natomiast jest osobistym aktem lub stanem, który wyraża się w zobo- 
wiązaniu wobec czegoś lub kogoś, czemu lub komu człowiek powierza siebie i poświęca ${ }^{32}$.

Religii zatem nie tylko można, ale wręcz powinno się nauczać. Jest to zadanie należące do instytucji. Z kolei wiary można się jedynie uczyć, wobec siebie i innych potwierdzać, uświadamiać, sprawdzać, przeżywać, wyznawać, ale nigdy nauczać. Przede wszystkim zaś niczego tu nie trzeba, ponieważ wiara jest osobowym aktem wolnych ludzi. Poza tym jest rzeczą wręcz pewną, że nauczana i praktykowana religia ma wpływ na osobistą wiarę. Natomiast ona sama nie powinna być nauczana.

6. Religia jest częścią europejskiej kultury, także w jej zsekularyzowanej formie. Nie można jej zrozumieć bez odniesienia do religijnych początków jej instytucji, form, świata wartości. Etyka, sztuka, nauka, porządek społeczny rozwinęły się z religii lub z konfrontacji z religią. Ogólne wykształcenie - także ateisty - nie może być w kontekście kultury Zachodu naprawdę „ogólne” i pełne, jeśli pomija religię. To, że oddzielone od Kościoła nowoczesne państwo udziela w swych neutralnych światopoglądowo szkołach lekcji religii - i to z podziałem na wyznania - jest według H. von Hentiga anachronizmem. Autor opiera się tu na przykładzie własnego kraju. Oba wielkie Kościoły w Niemczech (katolicki i protestancki) podtrzymują ten przeżytek, ponieważ nie chcą utracić strefy wpływów. Zabezpieczenie swych interesów widzą bardziej w podpisanych z państwem porozumieniach niż w poszukiwaniu nowych form dotarcia do dzieci i młodzieży zgodnie z osiągnięciami „wolnej katechetyki”. H. von Hentig uważa takie podejście za niewłaściwe. W szkole wolnej od prawnych ograniczeń H. von Hentig nie określałby nauczania religii tym mianem, a tradycyjnie przypisane mu tematy podzieliłby między inne przedmioty. Wprowadziłby natomiast kurs o nazwie „Historia biblijna”. Po opowiadaniach biblijnych następowałyby historie związane z męczennikami i świętymi, wielkimi kobietami i mężczyznami Kościoła, ale również z ich przeciwnikami i ofiarami: opowieści o Franciszku z Asyżu i Ignacym z Loyoli, o Lutrze i Janie XXIII, o Dioklecjanie i Sulejmanie Wspaniałym. O prześladowanych przez Kościół, Żydach i kacerzach, czarownicach i Inkach;

32 Jest to rozróżnienie dość powszechnie przyjmowane w filozofii religii. Jedynie Immanuel Kant reprezentował stanowisko przeciwstawne: „Jest tylko jedna prawdziwa religia, ale może istnieć wiele rodzajów wiary... Dlatego zręczniej jest powiedzieć: ten człowiek jest takiej albo innej (żydowskiej, mahometańskiej, chrześcijańskiej, katolickiej, luterańskiej) wiary, niż od jest takiej czy innej religii” I. Kant, Die Religion innerhalb der Grenzen der bloßen Vernunft, w: Werke in sechs Bänden, t. IV, Darmstadt 1970, s. 768 (wydanie polskie np.: I. Kant, Religia w obrębie samego rozumu, Kraków 2007). W ogólnym użyciu propozycja I. Kanta nie zyskała szerszej akceptacji. 
o misjonarzach i konkwistadorach - jednym słowem o pięknych i nikczemnych uczynkach ludzi Kościoła, o dobrodziejstwach i pomyłkach, które związane są $\mathrm{z}$ religią.

7. H. von Hentig przechodzi do omówienia przebiegu kursów biblijnych ${ }^{33}$. Kieruje się zasadą, że najlepiej rozpoznajemy to, co już znamy, a zatem ludzkie postrzeganie uzależnione jest w dużej mierze od stałych schematów. W historiach ze Starego i Nowego Testamentu odkryć można podstawowe ludzkie przeżycia. Jak dalece to możliwe, człowiek zbiera nowe doświadczenia, zastępczo uczestnicząc w biblijnych wydarzeniach bądź dzieląc los biblijnych postaci.

Każda jednostka lekcyjna kursu „Historii biblijnej” składa się z trzech elementów: przeżycia, wysłuchania opowiadania oraz przyswojenia (przez odtworzenie, konfrontację lub językowe i myślowe uporządkowanie). Zawsze chodzi o pewien zamknięty epizod, starannie przygotowany, opowiedziany żywo, szczegółowo i własnymi słowami. Następnie dzieci przygotowują przedstawienie. Odgrywają w scence to, o czym właśnie usłyszały i co przeżyły - zawsze jedna połowa dla drugiej i potem raz jeszcze na odwrót. Omówienie tych inscenizacji następuje tydzień później na rozpoczęcie kolejnych zajęć i stanowi jednocześnie powtórzenie. Zaczyna się od dobrze przemyślanych pytań ze strony nauczyciela, a kończy zwykle (jeśli rozmowa $\mathrm{z}$ dziećmi jest umiejętnie poprowadzona) zapytaniem ze strony uczniów: „A pani/pan naprawdę w to wierzy?". Kluczem do sukcesu jest, by katecheta mógł szczerze odpowiedzieć: „Tak, wierzę w to. Może nie do końca wiem, jak to było i nie zawsze rozumiem motywy bohaterów biblijnych opowiadań, ale wierzę, że w ich życiu działał Bóg, pisząc historię zbawienia".

8. Taki nauczyciel będzie wybierał historie tak, by mógł je opowiedzieć w sposób przekonujący. Jest wiele fragmentów w Starym i Nowym Testamencie, które jego samego nie poruszają. Gdy opowiada je własnymi słowami, będzie nadawał im mniejszą lub większą rangę, taką czy inną interpretację. Dlatego w niektórych wypadkach będzie uzasadnione, by odczytać tekst biblijny także w dosłownym brzmieniu.

9. Wybrane tematy lekcji religii, które mogą dać impuls i okazję do uczenia się wiary, są zdaniem H. von Hentiga następujące: zestawienie ze sobą Chrystusa i innych nauczycieli (np. Sokratesa), porównanie religii chrześcijańskiej z etyką bez przykazania miłości i bez kochającego Stwórcy czy wreszcie wymiana poglądów, na czym współcześnie może polegać naśladowanie Chrystusa.

33 Por. też. H. von Hentig, Bibelarbeit. Verheißung und Verantwortung für unsere Welt, München1988. 
10. Ostatnia myśl, dotycząca matetyki wiary według H. von Hentiga, ma charakter bardziej ogólny. Zdaniem autora pokazuje głęboką wiarę ktoś, kto nie tyle chce nauczać o chrześcijaństwie, lecz przede wszystkim nim żyć, to znaczy dawać innym przykład. Jeśli aktualnie nie jest w stanie, bo jego wiara jest chwiejna czy słaba, nie powinien - czekając na jakieś przełomowe doświadczenie - próbować niczego wymuszać. Nadzieja, że sens pojawi się sam w życiu człowieka, stanowi większą część wiary. Natomiast niecierpliwość i pośpiech, z jakimi dąży się czasem, by doprowadzić innych do wiary, oraz obawa o dalsze istnienie Kościoła z drugiej strony są świadectwem słabej wiary w ducha chrześcijańskiej religii.

Analizując przestawiony wyżej dość drobiazgowo wywód H. von Hentiga na temat matetyki wiary, trudno dopatrzyć się w nim spójnego systemu. To raczej garść myśli - niewątpliwie ciekawych i skłaniających do refleksji - na których dopiero można zacząć budować zręby zwartej koncepcji. Mieszają się w nich idee ogólne i uniwersalne ze szczegółowymi wnioskami lub propozycjami opartymi na osobistych doświadczeniach i incydentalnych sytuacjach. Niektóre z nich są osadzone w specyficznym kontekście niemieckiej pobożności i polityczno-społecznych warunków działalności Kościołów w tym kraju.

Cenne jest rozróżnienie religii (jako czegoś instytucjonalnego, czego można nauczać) i wiary (jako rzeczy osobistej, której można się uczyć, ale nie nauczać). Autor nie definiuje jednak obu pojęć, a co więcej, nie trzyma się konsekwentnie zaproponowanego podziału. Dlatego czasem można odnieść wrażenie, że u H. von Hentiga wiara jest rzeczywistością, nad którą człowiek panuje, którą można po ludzku wywołać i zaaranżować jak towarzyskie spotkanie. Tymczasem $\mathrm{z}$ teologicznego punktu widzenia jest to stanowisko nie do utrzymania. Gdy autor przykładowo stawia pytania o taką wiarę, która możliwa jest do nauczenia się i jednocześnie nieuzależniona od Objawienia lub przeżyć religijnych, zdaje się budować podstawy dla religii naturalnej, a zatem wpada w pułapkę myślenia oświeceniowego, z której - jak sugeruje tytuł jego książki - chciał wiarę uwolnić. Gdy H. von Hentig przestaje przestrzegać podziału na wiarę i religię, dochodzi do paradoksów i nieścisłości.

W czasie lekcji religii/katechez opartych na matetyce uczą się wszyscy od siebie nawzajem. Uczą się przede wszystkim tego, jak patrzy się na świat z wiarą i jak wygląda on bez wiary. Najistotniejsze jednak zdaniem H. von Hentiga jest to, by nauczyciel religii/katecheta był człowiekiem wierzącym. W przeciwnym razie zajęcia biblijne i każde nauczanie religijne będą „nie-wiary-godne”. Nie powinno się ich w ogóle prowadzić, jeśli zabraknie kogoś, kto może powiedzieć: „Tak, wierzę w to”. Trudno się z tą opinią sędziwego pedagoga nie zgodzić. 


\title{
TERM OF THE MATHETICS \\ IN MODERN PEDAGOGICAL AND CATECHETIC DISCOURSE. AN OUTLINE OF ISSUES
}

\author{
Summary
}

Mathetics as a complementation of didactics assumes a constructivist conception of learning understood as a dynamic, autopoietic (self-organized) process, during which man creates his own reality. Mathetics involves an integral way of looking at the pupil and views the course of learning from his perspective. In consequence, teaching starts to be understood as an ordered and comprehensive offer addressed to the pupil, in which not only content transmission but also the plane of relations plays a significant role. This in turn leads to a process of learning where not just the pupils' reason but their emotions, motivations and will also come to the fore.

With regard to religious education and catechesis, mathetics means that all those concerned learn the faith from one another. First and foremost they learn what it is like to see the world through faith and what the world looks like without faith. What is most important, however, is that the religion teacher/catechist should be a person of faith, because only then will they be credible.

Slowa kluczowe: matetyka, uczenie się, dydaktyka, katecheza, J.A. Komenský

Key words: mathetics, learning, theory of teaching, catechesis, J.A. Comenius

\section{BIBLIOGRAFIA}

Abram I., Judentum und permanentes Lernen, w: Lehren und Lernen in jüdisch-christlicher Tradition. Erfahrungen aus den Niederlanden, red. U. F. W. Bauer, A. H. Wöhle, Knesebeck 1995.

Anton M.A., Erziehen und Sich-bilden - Lehren und Lernen - Didaktik und Mathetik, [w:] „Lernwelten" 2 (2003).

Chott P.O., Die Entwicklung des MATHETIK-Begriffs und seine Bedeutung für den Unterricht der (Grund-)Schule, „Pädagogisches Forum: unterrichten erziehen” 4 (1998), s. 392.

Dingemans G.D.J., In de leerschool van het geloof. Mathetiek en vakdidactiek voor catechese en kerkelijk vormingswerk (Handboek praktische theologie, Band 3), Kampen 1986, s. 15.

Dingemans G.D.J., Manieren van doen. Inleiding tot de studie van de praktische theologie, Kampen 1996.

Encyklopedia pedagogiczna XXI wieku, t. 3, M-O, red. prowadzący E. Różycka; autor t. 3 F. Adamski i in., Warszawa 2004.

Encyklopedia pedagogiczna, red. W. Pomykało, Warszawa 1993.

Gilbert T.F., Mathetics: An explicit theory for the design of teaching programmes, London 1969.

Gilbert T.F., Mathetics: The technology of education, „The Journal of Mathetics” 1 (1962).

Gilbert T.F., Some issues in mathetics. I saying what a subject matter is, „Performance Improvement" 2 (1969), s. 4-19.

Hentig v. H., Bibelarbeit. Verheißung und Verantwortung für unsere Welt, München 1988. 
Hentig v. H., Glaube. Fluchten aus der Aufklärung, Düsseldorf 1992.

Hentig v. H., Wie frei sind Freie Schulen? - Gutachten für ein Verwaltungsgericht, Stuttgart 1985.

Kant I., Die Religion innerhalb der Grenzen der bloßen Vernunft, [w:] Werke in sechs Bänden, t. IV, Darmstadt 1970 (wydanie polskie np.: I. Kant, Religia w obrębie samego rozumu, Kraków 2007).

Kohlberg W.D., Unseld T., Mathetik. Mathetik des E-Learnings (s. 1-34); Mathetics. Mathetics of E-Learning (s. 35-64); Mathétique. Mathétique du E-Learning (s. 65-96), Osnabrück 2007.

Koizumi H., Wie funktioniert das Gehirn?, Paris 2003, s. 113n.

Komenský J.A., Spicilegium didacticum artium discendi ac docendi summam brevibus praeceptis exhibens. MSStis Cl. J. A. Comenii collectum et editum a C. V. N. Amstelodami typis Christophori Cunradi. Anno 1680. (red. Ján Kvačala). Nunc editum Rosenbergae: Typis Caroli Salva, 1895. Dostępny w Internecie w formie zdygitalizowanej: www.digitalniknihovna.cz/mzk/uuid/ uuid:211e1470-6168-11e4-8b87-001018b5eb5c (plný text), [dostęp 27 czerwca 2018].

Komenský J. A., Wielka dydaktyka, obejmująca cała sztukę nauczania wszystkiego wszystkich, wstępem i komentarzem opatrzył Henryk Wernic, Warszawa 1883, s. 4-8.

Kösel E., Die Modellierung von Lernwelten, Elztal-Dallau 1993.

Kupisiewicz C., Kupisiewicz M., Stownik pedagogiczny, Warszawa 2009.

Mette N., Religionspädagogik, Düsseldorf 2000.

Okoń W., Nowy stownik pedagogiczny, Warszawa 2001.

Okoń W., Stownik pedagogiczny, Warszawa 1992.

Pedagogika, red. B. Milerski, B. Śliwerski, Warszawa 2000.

Witwicki W., Platon jako pedagog, w: Z dziejów myśli pedagogicznej, red. B. Suchodolski, W. Okoń, Warszawa 1958.

Wołoszyn S., Pedagogika sofistów. Studium z dziejów antycznej kultury pedagogicznej, [w:] Z dziejów myśli pedagogicznej, Warszawa 1958. 